\title{
Analysis of Disease-free Survival and Overall Survival in Patients with Luminal A Breast Cancer Stratified According to TNM
}

\author{
Analýza celkového přežití a celkového bezpřiznakového přežití \\ u pacientek s luminálním karcinomem A v závislosti \\ na TNM stadiu
}

Borges G. S. ${ }^{\text {, }}$ Colchon P. H. ${ }^{2}$, Staak M. C. Jr. ${ }^{2}$, Girardi F. ${ }^{2}$, Rosar K. Ch. ${ }^{2}$, Zamboni F. M. ${ }^{3}$, Grazziotin L. F. S. ${ }^{2}$, Rebello J. R. ${ }^{3}$, Ribeiro M. A. ${ }^{1}$, Felippe G. C. ${ }^{1}$, Rovere R. K. ${ }^{4}$

\author{
'Oncologia, Clínica de Neoplasias Litoral, Itajaí, Santa Catarina, Brazil \\ 2 Primary Doctor, Itajaí, Santa Catarina, Brazil \\ ${ }^{3}$ Universidade do Vale do Itajaí, Itajaí, Santa Catarina, Brazil \\ ${ }^{4}$ Oncology Unit, Santo Antonio Hospital, Blumenau, Santa Catarina, Brazil
}

\begin{abstract}
Summary
Background and Aim: The TNM classification of malignant tumours is the most commonly used system to assess the stage as well as the prognosis of cancer. However, one of the biggest challenges in treatment of breast cancer is the understanding of tumour heterogeneity typical of these carcinomas. The aim of this study was to analyse the disease-free survival and overall survival in patients with luminal A subtype of breast cancer, stratified by TNM staging system. Methods and Study Design: A total of 363 medical records from January 2001 to May 2006 were evaluated for data collection. There were 136 patients with luminal A breast cancer, selected for the cohort. The main objective was the analysis of disease-free survival (DFS) and overall survival (OS) in patients with luminal A breast cancer, stratified according to the TNM classification. Results: The group of 136 patients with immunohistochemically defined luminal A subtype represented $53 \%$ of the 253 patients with breast cancer. There was no significant difference in the number and type of patients as for TNM stage and histological grading among patients treated with chemotherapy and $\mathrm{HT}$ in comparison to patients treated with HT alone. Conclusion: Our analysis did not prove any significant difference in survival of patients treated with chemotherapy followed by hormone therapy in comparison to patients treated with $\mathrm{HT}$ alone. We suggest that the IHC luminal A subtype of breast cancer generally warrants a good prognosis independently on other prognostic factors such as TNM stage. We conclude that patients might not benefit of adding a chemotherapy to hormonal therapy in adjuvant settings.
\end{abstract}

Key words

breast cancer - mastology - chemotherapy - hormonal therapy
The authors declare they have no potential conflicts of interest concerning drugs, products, or services used in the study.

Autor̆i deklarují, že $v$ souvislosti s predmětem studie nemaji žádné komerční zájmy.

The Editorial Board declares that the manuscript met the ICMJE "uniform requirements" for biomedical papers.

Redakční rada potvrzuje, že rukopis práce splnil ICMJE kritéria pro publikace zasílané do biomedicínských časopisů.

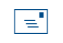

Rodrigo Kraft Rovere, MD

Oncology Unit

Santo Antonio Hospital

Rua Itajai 545

Blumenau, Santa Catarina

CEP 89050100 Brazil

e-mail: rodrigorovere@yahoo.com

Submitted/Obdrženo: 24. 11. 2013

Accepted/Príijato: 17. 12. 2013 


\section{Souhrn}

Východiska a cíl: TNM klasifikace patří mezi nejužívanější systémy k posouzení stadia a prognózy maligních onemocnění. Základní problematikou pak v terapii karcinomu prsu zůstává otázka heterogenity těchto nádoru. Cílem této práce je posouzení celkového a bezpř́znakového přežití u pacientek s luminálním karcinomem A s ohledem na jednotlivá stadia onemocnění dle TNM klasifikace. Metody a design studie: Bylo zhodnoceno celkem 363 zdravotnických záznamů z období od ledna 2001 do května 2006. Pro další analýzu bylo vybráno celkem 136 pacientek s luminálním karcinomem A. Primárním cílem studie bylo posouzení celkového a bezpríznakového přežití u vybraných pacientek se subanalýzou ukazatelů dle jednotlivých TNM stadií. Výsledky: Z celkového počtu 253 subjektů tvořilo podskupinu s luminálním karcinomemm A celkem 53 \% pacientek. Ve skupině pacientek léčených chemoterapií a hormonální léčbou ve srovnání s pacientkami léčenými pouze hormonoterapií nebyl prokázán signifikantní rozdíl v jejich počtu a skladbě dle TNM stadia a stupně diferenciace. Závěr: Nebyl zaznamenán signifikantní rozdíl v celkovém a bezpř́znakovém přežití u pacientek s karcinomem prsu léčených hormonoterapií a chemoterapií ve srovnání se skupinou pacientek léčených pouze hormonoterapií. Lze konstatovat, že diagnóza luminálního karcinomu A zaručuje dobrou prognózu nezávisle na stadiu nemoci a dalších prognostických faktorech. Na základě uvedených výsledků se domníváme, že prínos použití chemoterapie v kominaci s hormonoterapií v adjuvantní léčbě pacientek s karcinomem prsu zůstává sporný.

\section{Klíčová slova}

karcinom prsu - mastologie - chemoterapie - hormonoterapie

\section{Introduction}

Breast cancer is the most common type of cancer in a worldwide scope with over a million of new cases diagnosed annually [1]. In Brazil, mortality rates from the disease remain high, perhaps due to an advanced stage at the diagnosis [2]. The estimated incidence rate is 52 cases per 100,000 inhabitants in the country annually [3]. The incidence of breast cancer, correspondingly to other epithelial tumours, increases dramatically with age, doubling the number about every 10 years of age after the menopause [4]. TNM staging of malignant tumours is the most common system used to evaluate the prognosis of cancer. However, one of the biggest challenges in the study and treatment of breast cancer is the mapping of tumour heterogeneity typical of these carcinomas [5]. The morphological classification (pathology) itself is insufficient in the evaluation of breast carcinomas, since there are other variables such as histological type, grade, tumour size, lymph node status, oestrogen receptor (ER), progesterone (PR) and HER2 that influence the prognosis and sensitivity to systemic therapy [6].

By means of immunohistochemistry, breast cancer could be classified into four major subtypes - hormone receptor-positive luminal A and luminal B subtype, human epidermal growth factor receptor-type 2 (HER2) positive and triple negative (basal like) subtype [7]. The identification of markers that pro- vide predictive information on tumour behaviour is especially important in breast cancer, primarily due to variability of clinical course of the disease. Treatment strategies are dependent on the molecular profile of each tumour, while the risk of recurrence and the potential benefit from endocrine therapy and chemotherapy is under discussion [8].

The aim of this study was to analyse the disease-free survival (DFS) and overall survival (OS) in patients with luminal $A$ breast cancer stratified according to the TNM classification.

\section{Materials and methods}

The study population comprises women diagnosed with breast cancer who underwent follow-up at three medical centres - Mastology Sector from the Family and Community Health Unit at the University of Vale do Itajaí (UNIVALI); High Complexity Oncology Assistance Unit (Unacon), Hospital Marieta Konder Bornhausen, and Litoral Clinic of Neoplasms, all located in the city of Itajaí, SC, Brazil. A total of 363 medical records from January 2001 to May 2006 were evaluated for data collection.

Inclusion criteria were female sex breast cancer diagnosis (either unilateral or bilateral), clinical stage record and histopathological verification from a surgical specimen from January 2001 to May 2006. The specimens were examined for immunohistochemical (IHC) markers: oestrogen and progesterone receptor expression, HER2 status and Ki-67.
The tumor was considered oestrogen and progesterone receptor positive if immunostaining was observed in more than $1 \%$ of nuclei; a cut-off for Ki- 67 of $14 \%$ was chosen; HER2 overexpression required $3+\mathrm{IHC}$ test result, or $2+\mathrm{IHC}$ result confirmed by CISH or FISH test.

The patients with primary metastatic disease were excluded from the analysis of DFS. Patients with incomplete data concerning the variables mentioned above were excluded from the analysis.

Among the 363 records, 310 cases were subjected to pathological verification from 2001 to 2006. Fifty seven patients were excluded due to lacking follow-up. Out of the remaining 253 records, there were 136 cancer patients with immunohistochemically defined luminal A subtype selected for the study population.

The main objective was the analysis of DFS and OS in patients with luminal A breast cancer, stratified according to the TNM classification.

Further subanalyses involved comparison of DFS and OS with respect to treatment modality (chemotherapy + hormone therapy, hormone therapy alone or chemotherapy alone), chemotherapy agent, radiotherapy application, histological grade, and lymph node involvement.

The data were processed and analysed using descriptive statistical methods. Tests of sample variation distribution and chi-square test were applied for the 
analysis of sample homogeneity and causal factor verification, given a value for statistical significance $(p<0.05)$ with a confidence interval of $95 \%$. Subgroups comprising less than five subjects were not statistically analysed due to their small size.

The study was approved by the Committee of Ethics in Research of UNIVALI on 25th June 2010.

\section{Results}

Samples from 363 patients examined by immunohistochemical assays involved $53 \%$ (136 cases) of the luminal A, 18\% (48 cases) of luminal B, 20\% (52 cases) of triple negative (basal like) tumors and $6 \%$ (17 cases) of HER2 overexpression.

The results of disease-free survival (DFS) and overall survival (OS) analysis in patients with luminal $A$ breast cancer are shown in tab. 1. One-year DFS rate achieved $94.5 \%$, two-year DFS $88.97 \%$, and three-year DFS $86.03 \%$. One-year OS was $98.53 \%$, two-year survival accounted for $94.85 \%$, and three-year OS rate was $93.38 \%$. A hundred and twenty patients have completed the study period. The DFS and OS values at a time period of 12 and 24 months did not show statistically significant differences, ( $p=0.09$ and $p=0.075$ respectively), however, they reached a statistical significance at the three-year time interval.

Graph 1 shows the OS and DFS in patients with luminal $A$ breast cancer as mentioned above.

Table 2 shows the DFS and the OS allocated by clinical stage of the disease. The most frequent stages observed were stage IIA and IIB, comprising 34 cases each. Stage I involved 21 cases, stage IIIB (18 cases), stage IIIA (10 cases), stage 0 (8 cases) and stage IV (1 case). By chi-square test of adhesion the sample was proved heterogenous at $p=0.001$ and the stage IIA and IIB involvement was significantly higher.

Eight patients presented with a stage 0 disease with three-year DFS and OS reaching only $87.5 \%$. Compared with stage I (21 cases), the DFS $(p=0.90)$ and OS $(p=0.46)$ showed a nonsignificant increased. Comparing stage I and IIA groups (34 cases), there was no statistical difference reached in terms of DFS $(p=0.96)$ and

Tab. 1. General DFS and OS in luminal A patients (\%).

\begin{tabular}{|l|c|c|c|}
\hline & $\mathbf{1 2}$ months & 24 months & 36 months \\
\hline DFS Luminal A & $94.85 \%$ & $88.97 \%$ & $86.03 \%$ \\
\hline OS Luminal A & $98.53 \%$ & $94.85 \%$ & $93.38 \%$ \\
\hline
\end{tabular}

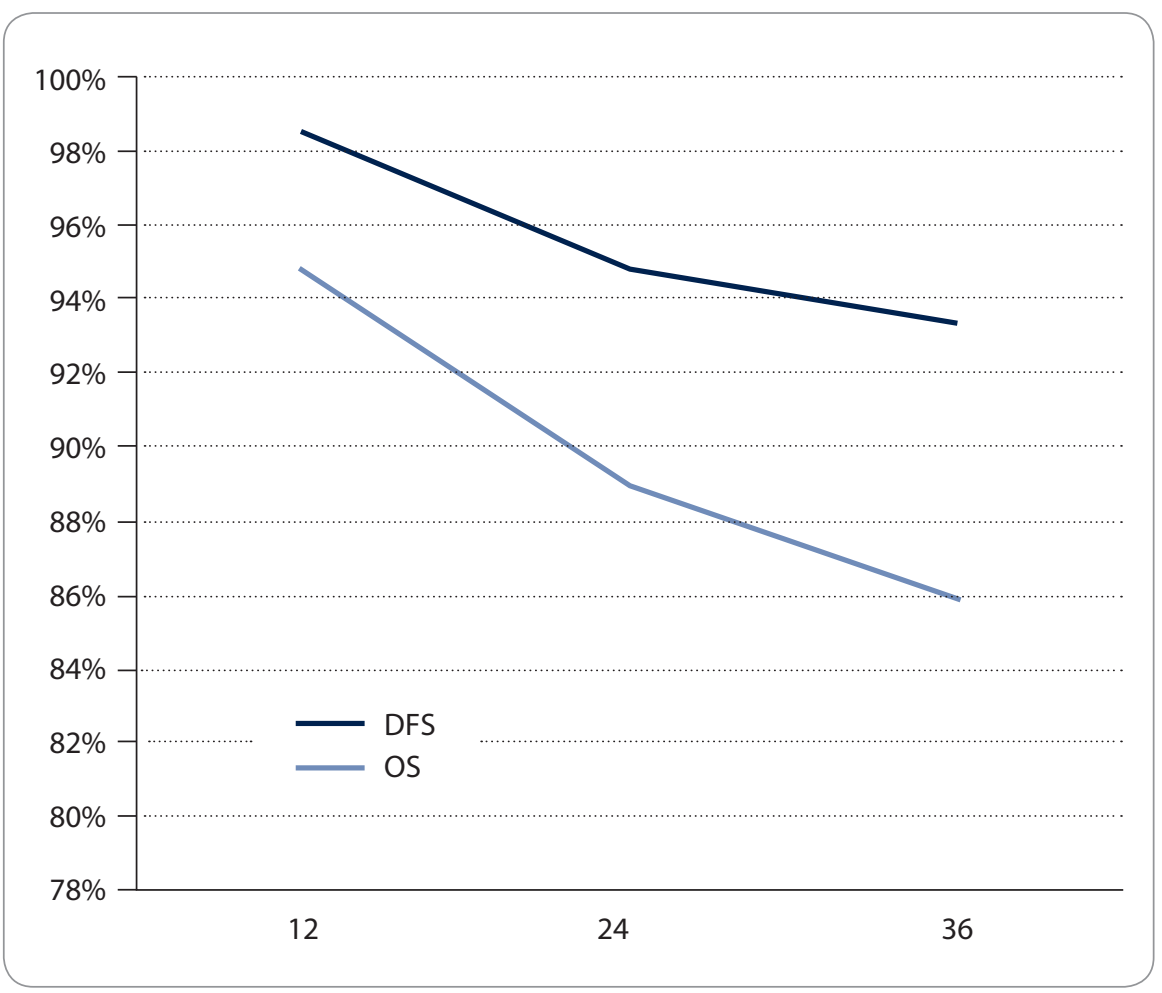

Graph 1. Overall survival and disease-SG 12, 24 and 36 months in luminal A patients (\%).

OS $(p=0.85)$. Similarly, we found no differences between stage IIA and IIB (34 cases) as for the DFS and OS values at $p=1$. Comparing the stage IIB and IIIA (10 cases) we found $p=0.70$ and $p=0.43$ for SLD for SG and IIIA and IIIB (18 cases) with $p=0.92$ and $p=0.27$ for SLD to SG, i.e., there were no statistically significant difference between these stages.

Patients with luminal A breast cancer (136) received either chemotherapy prior to endocrine therapy or hormone therapy alone.

We evaluated the OS and DFS stratified by TNM staging with the treatment modality as an independent variable (chemotherapy, hormone therapy or none) as shown in the tab. 3 .

Most frequently applied chemotherapy regimens were CMF (cyclophosphamide + methotrexate + fluoroura- cil) in 37 cases and FAC (adriamycin + cyclofostamida with or without fluorofluorouracil-5) in 30 cases. Other chemotherapies included ACT (cyclophosphamide + doxorubicin + paclitaxel) and FEC (5-fluorouracil + epirubicin + cyclophosphamide) with an unspecified regimen in one case. There was no significant difference in OS and DFS associated with any type of chemotherapy.

Radiotherapy was performed in 71 patients (52.2\%), however, it did not yield any significant change in DFS and OS rate.

This study encompasses 65 (47\%) grade II tumours 23 cases (16\%) of grade III tumours, 6 cases (4\%) classified as grade I tumours and 42 specimens unavailable for histological analysis. Chi-square test of adhesion revealed that the sample was not uniform and 
Tab. 2. Survival and disease-free survival at 12, 24 and 36 months according to the TNM clinical stage (\% and absolute numbers).

\begin{tabular}{|c|c|c|c|c|c|}
\hline TNM Stage & & 12 months & 24 months & 36 months & Total of patients \\
\hline \multirow{2}{*}{ stage 0} & DFS & $87.50(7)$ & $87.50(7)$ & $87.50(7)$ & \multirow{2}{*}{$100(8)$} \\
\hline & OS & $87.50(7)$ & $87.50(7)$ & $87.50(7)$ & \\
\hline \multirow{2}{*}{ stage I } & DFS & $95.24(20)$ & 90.48 (19) & $85.71(18)$ & \multirow{2}{*}{$100(21)$} \\
\hline & OS & $100.0(21)$ & $95.24(20)$ & $95.24(20)$ & \\
\hline \multirow{2}{*}{ stage IIA } & DFS & $97.06(33)$ & $88.24(30)$ & $85.29(29)$ & \multirow{2}{*}{$100(34)$} \\
\hline & OS & $100.0(34)$ & $97.06(33)$ & $94.12(32)$ & \\
\hline \multirow{2}{*}{ stage IIB } & DFS & $94.12(32)$ & $88.24(30)$ & $85.29(29)$ & \multirow{2}{*}{$100(34)$} \\
\hline & OS & $97.06(33)$ & $97.06(33)$ & $94.12(32)$ & \\
\hline \multirow{2}{*}{ stage IIIA } & DFS & $100.0(10)$ & $100.0(10)$ & $90.0(9)$ & \multirow{2}{*}{$100(10)$} \\
\hline & OS & $100.0(10)$ & $100.0(10)$ & $100.0(10)$ & \\
\hline \multirow{2}{*}{ stage IIIB } & DFS & 94.44 (17) & $88.89(16)$ & $88.89(16)$ & \multirow{2}{*}{$100(18)$} \\
\hline & OS & $100.0(18)$ & $88.89(16)$ & $88.89(16)$ & \\
\hline \multirow{2}{*}{ stage IIIC* } & DFS & - & - & - & \\
\hline & OS & - & - & - & \\
\hline \multirow{2}{*}{ stage IV } & DFS** & - & - & - & \\
\hline & OS & $0(1)$ & - & - & 1 \\
\hline
\end{tabular}

*in the sample there were no patients in stage IIIC

stage IV **excluded from the DFS analysis

Tab. 3. Absolute number of patients with DFS and OS who underwent treatment according to TNM staging at the end of 36 months follow-up.

\begin{tabular}{|c|c|c|c|c|c|c|c|c|}
\hline TNM & & 0 & I & II & III & IV & Excluded & Total \\
\hline \multirow{2}{*}{$\mathrm{CT}+\mathrm{HT}$} & DFS & $1(2)$ & $10(11)$ & $38(41)$ & $12(12)$ & - & 3 & \multirow{2}{*}{$\begin{array}{c}70 \\
(51.47 \%)\end{array}$} \\
\hline & OS & $1(2)$ & $10(11)$ & $41(41)$ & $12(12)$ & 0 & & \\
\hline \multirow{2}{*}{ HT } & DFS & $5(5)$ & $7(8)$ & $18(21)$ & $10(11)$ & - & 4 & \multirow{2}{*}{$\begin{array}{c}49 \\
(36.03 \%)\end{array}$} \\
\hline & OS & $5(5)$ & $8(8)$ & $19(21)$ & $11(11)$ & - & & \\
\hline \multirow{2}{*}{$\mathrm{CT}$} & DFS & - & - & $0(1)$ & $0(1)$ & - & & \multirow{2}{*}{$\begin{array}{c}2 \\
(1.47 \%)\end{array}$} \\
\hline & OS & - & - & $1(1)$ & $0(1)$ & - & & \\
\hline \multirow{2}{*}{$\begin{array}{l}\text { no } \\
\text { treatment }\end{array}$} & DFS & $1(1)$ & $1(2)$ & $2(5)$ & $3(4)$ & - & 3 & \multirow{2}{*}{$\begin{array}{c}15 \\
(11 \%)\end{array}$} \\
\hline & OS & $1(1)$ & $2(2)$ & $3(5)$ & $3(4)$ & - & & \\
\hline total & & 8 & 21 & 68 & 28 & 1 & 10 & $\begin{array}{c}136 \\
(100 \%)\end{array}$ \\
\hline
\end{tabular}

grade II tumours were significantly more frequent. The analysis of DFS and OS rates with regard to histological grades at each stage showed no statistical difference in the values.

\section{Discussion}

The TNM staging system alone did not proved to be sufficient for evaluation of breast cancer. The discovery of the "diseases within the disease" model of breast cancer behaviour in the past years, shifted the focus of treatment to novel standards based on specific tumour characteristics beyond the staging system.

Our goal was to emphasize that, the treatment strategy of a luminal A breast cancer, with a relatively good prognosis, should not be based solely on TNM stage of the disease.

Our analysis of OS and DFS rate of luminal A cancer yielded results consistent with other similar studies $[9,10]$.

The use of HT and chemotherapy plays a crucial role in the treatment of breast cancer. The analysis of patients receiving chemotherapy and/or HT revealed that chemotherapy did not result in substantial improvement of DFS and OS. The histological grade of tumour specimen is another common prognostic parameter reflecting the malignant potential of tumour and its capacity to metastasise [8]. The majority of patients were diagnosed with grade II tumours, in accordance with other studies [10]. This work did not demonstrate statistically significant difference in DFS and OS in this group of patients, suggesting that the histological grade does not interfere with SG and SLD of patients with luminal breast cancer $A$.

The extent of surgical procedure including axillary dissection is regarded an important prognostic factor and 
provides a clue to further treatment plan [11]. The distribution of patients with axillary lymph nodes involved was similar to data from other available studies [9]. As a matter of fact, patients without metastatic axillary lymph node involvement have a better prognosis with regard to both OS and DFS. Nevertheless, our study did not demonstrate a significant difference in DFS and OS between these two groups of patients, perhaps due to the selection of patients limitted to luminal A breast cancer, with inherently low likelihood of axillary lymph node involvement.

\section{Conclusion}

This study demonstrates trends that might appear relevant in handling a patient with luminal A breast cancer, although the sample size is not sufficient to extrapolate the results to the general population.

We conclude that DFS and OS rates of luminal A breast cancer are mutualy corresponding, at least in the early years of the disease. The number of patients diagnosed at advanced stages is alarm- ingly high in our geographical settings. The histological grade did not prove to affect the survival rates of the study population.

Furthermore, our analysis showed that patients did not benefit of adding chemotherapy to hormonal therapy in adjuvant settings, and there was neither an agent-specific difference observed. The radiotherapy employment in the management of the disease had no impact on recurrence rate, the OS or DFS, however, the results could be biased by an insufficient sample size. In the study population with luminal $A$ breast cancer the lymph node status did not affect the DFS and OS. Thus, we suggest that the IHC luminal A subtype of breast cancer generally warrants a good prognosis possibly masking other prognostic factors such as TNM stage and other parameters that normally underline differences in survival rates throuhout all IHC subtypes.

Hence, we emphasize a need for further studies with on larger study population with a longer follow-up period in order to prove our results.

\section{References}

1. Jemal A, Bray F, Center MM et al. Global cancer statistics. CA Cancer J Clin 2011; 61(2): 69-90.

2. Schwartsmann G. Breast cancer in South America: challenges to improve early detection and medical management of a public health problem. J Clin Oncol 2001; 19 (Suppl 18): S118-S124

3. De Castro Mattos JS, Mauad EC et al. The impact of breast cancer screening among younger women in the barretos region, Brazil. Anticancer Res 2013; 33(6): 2651-2655.

4. McPherson K, Steel CM, Dixon JM. ABC of breast diseases. Breast cancer-epidemiology, risk factors, and genetics. BMJ 2000: 321(7261): 624-628.

5. Viale G. The current state of breast cancer classification. Ann Oncol 2012; 23 (Suppl 10): x207-x210.

6. Aebi S, Davidson T, Gruber G et al. Primary breast cancer: ESMO Clinical Practice Guidelines for diagnosis, treatment and follow-up. Ann Oncol 2011; 22 (Suppl 6): vi12-vi24.

7. Cancer Genome Atlas Network. Comprehensive molecular portraits of human breast tumours. Nature 2012; 490(7418): 61-70.

8. Sotiriou C, Pusztai L. Gene-expression signatures in breast cancer. N Engl J Med 2009; 360(8): 790-800.

9. Carey LA, Perou CM, Livasy CA et al. Race, breast cancer subtypes, and survival in the Carolina breast cancer study. JAMA 2006; 295(21): 2492-2502.

10. Zaha DC, Lazar E, Lazureanu C. Clinicopathologic features and five years survival analysis in molecular subtypes of breast cancer. Rom J Morphol Embryol 2010; 51(1): 85-89.

11. Koca E, Kuzan TY, Dizdar O et al. Outcomes of locally advanced breast cancer patients with $\geq 10$ positive axillary lymph nodes. Med Oncol 2013; 30(3): 615 